\title{
REGULAR ARTICLE \\ EVALUATION OF BRASSICA JUNCEA GERMPLASM THROUGH HERITABILITY ESTIMATION AND CORRELATION ANALYSIS
}

\author{
FAWAD ALI ${ }^{*}$, BAKHAT HUSSAIN ${ }^{2}$, JAVED ALI ${ }^{1}$, MEHRAN AYOOB TUNIO ${ }^{1}$
}

${ }^{1}$ Department of Plant Sciences, Quaid-I-Azam University, Islamabad, Pakistan

2Department of Plant Breeding and Genetics, Sindh Agriculture University, Tandojam, Pakistan

\begin{abstract}
The experiment was conducted to estimate genetic parameters of heritability and correlation for yield traits of indigenous Brassica juncea genotypes. RCB design with three replications was used to sow 20 Brassica genotypes. Highly significant genetic variations were obtained among studied parameters. Days to half flowering revealed positive associations with primary branches per plant $\left(\mathrm{r}=0.337^{* *}\right)$. Primary branches per plant was positively correlated with pod length $\left(\mathrm{r}=0.407^{* *}\right)$, seed per pod $\left(\mathrm{r}=0.418^{* *}\right)$ seed yield per plant $\left(\mathrm{r}=0.479^{* *}\right)$. Similarly, pod length showed positive correlation with seed per pod $\left(\mathrm{r}=0.324^{*}\right)$ and seed yield per plant $\left(\mathrm{r}=0.331^{* *}\right)$, while seed per pod was positively correlated with seed yield per plant $\left(\mathrm{r}=0.878^{* *}\right)$. Highest broad-sense heritability was recorded for seed yield per plant (0.97), while lowest heritability was estimated for primary branches per plant (0.46).
\end{abstract}

Keywords: Brassica, Heritability, Correlation

\section{INTRODUCTION}

Edible oil is on the top in the imported bill of Pakistan mainly due to low local production. Brassica oilseed is the third edible oil source after Palm and Soybean world widely [1]. This high dependency on imported oil can be reasonably decreased by the development of oilseed genotypes having better adaptability into the cropping system of Pakistan [2]. Seed yield can be improved by improving parameters having high genetic divergence, heritability and selection response [3]. To run an effective breeding program, high heritability along with high selection response is desirable because a good understanding of selection response is helpful in the selection process [4]. It must be noted that high heritability with high selection response is an indication of additive genetic operation, while parameters with high heritability but low selection response is due to operations other than additive genes [5].

Evaluation of the variability among the genetic resources of the material is the top priority for the improvement because it generates necessary information which can speed up the breeding program [6, 7]. The necessary tools for the genetic improvement of crop plants in a breeding program are divergence among the material and parameters having high heritability with high selection response [8]. Selection response is a very useful tool which shows the extent of increment of a parameter under study and can be easily calculated with the help of heritability estimates. It helps the breeder to proceed in a right way [9]. Correlation analysis is very helpful in understanding relationship between different sets of parameters [10].

\section{MATERIALS AND METHODS}

The planned study was conducted at the University of Agriculture, Peshawar during 2011-12 to estimate genetic parameters of heritability and correlation analysis among 20 Brassica genotypes. The research material was planted in RCB design with three replicates. Data were recorded on six agro-morphological and maturity parameters. Fifteen plants were selected for data recording in a single replication.

\section{Statistical analysis}

LSD test was used for means separation. Steel and Torrie [11] approach was used for the computation of analysis of variance. Broad-sense heritability estimates were recorded as a ratio of genotypic variance to the total phenotypic variance [12]. Selection response was calculated using Fehr [13] approach having selection intensity of $20 \%$.

\section{RESULTS AND DISCUSSION}

Results and discussion describing heritability estimation and correlation analysis among 20 Brassica juncea genotypes are given below.

\section{Days to half flowering}

Days to half flowering showed significant $(P \leq O .01)$

\footnotetext{
Received 07 December 2017; Accepted 31 December 2017

*Corresponding Author

Fawad Ali

Department of Plant Sciences, Quaid-I-Azam University, Islamabad, Pakistan

Email: fawadali365@gmail.com

(CThis article is open access and licensed under the terms of the Creative Commons Attribution License (http://creativecommons.org/licenses/by/4.o/) which permits unrestricted, use, distribution and reproduction in any medium, or format for any purpose, even commercially provided the work is properly cited. Attribution - You must give appropriate credit, provide a link to the license, and indicate if changes were made.
} 
differences among 20 genotypes (table 1). Our results are strongly supported by the previous findings [10, 14, 15]. Days to half flowering ranged from 58.00 to $89.00 \mathrm{~d}$. Maximum days to half flowering (89.00 d) were observed in genotype J.600, whereas minimum days (58.00 d) were found in genotype J.617 (table 2). Genetic variance (40.02) was greater than environmental variance (37.53) for days to half flowering. Moderate broad-sense heritability (0.52) and high selection response (6.54) were recorded for the said trait (table 3). Our current findings are in contradiction with Mahto and Haider [16], who reported high broad-sense heritability which discourages our results but their findings agree with our results of obtaining moderate to high selection response for days to flowering. Highly significant and positive correlation were recorded between days to half flowering and primary branches per plant $\left(\mathrm{r}=0.337^{* *}\right)$ (table 4). Positive but non-significant associations between days to half flowering and primary branches per plant were noted by Nasim et al. [17] and strengthen our findings.

\section{Primary branches plant ${ }^{-1}$}

For primary branches plant ${ }^{-1}$, highly significant $(P \leq O . O 1)$ differences were computed from analysis of variance (table 1). Previous studies reported significant variation for the said trait and encourage our findings $[18,19,20]$. Primary branches plant ${ }^{-1}$ ranged from 8.3 to 15.7 . Maximum primary branch plant ${ }^{-1}$ (15.7) was observed in genotype J.600, while genotype J.617 exhibited minimum number of primary branches (8.3) (table 2). Genetic variance (2.97) was lower in magnitude than environmental variance (3.53). Moderate broad-sense heritability (0.46) and low selection response (1.68) were recorded for the said trait (table 3). Our results are contradicted by the findings of Iqbal et al. [21] who observed high broad-sense heritability but are in agreement by reporting low selection response value. Low heritability estimates were obtained by Zhang and Zhou [1], for the said parameter. Primary branches plant ${ }^{-}$ ${ }^{1}$ showed significant and positive associations with pod length $\left(\mathrm{r}=0.407^{* *}\right)$, seed $\operatorname{pod}^{-1}\left(\mathrm{r}=0.418^{* *}\right)$ and seed yield $\left(r=0.479^{* *}\right)$ (table 4$)$. Positive and significant associations among primary branches plant ${ }^{-1}$ with pod length, seed pod $^{-1}$ and seed yield were reported by Ali et al. [2] which confirmed our finding.

\section{Main raceme length}

Analysis of variance indicated significant $(P \leq O . O 1)$ differences for the said parameter (table 1). Zada et al. [7] observed significant differences in Ethiopian mustard. Our findings are also in similarity with the previous results [22, 14]. Main raceme length ranged from 40.1 to $77.8 \mathrm{~cm}$. Maximum main raceme length $(77.8 \mathrm{~cm})$ was observed in genotype J.616, whereas minimum raceme length $(40.1 \mathrm{~cm})$ was found in genotype J.600 (table 2). Genetic variance (73.26) was greater in amount than environmental variance (53.86) for main raceme length. Moderate broad-sense heritability (0.58) and high selection response (9.36) were recorded for studied trait (table 3). Muhammad et al. [23] recorded moderate broad-sense heritability and extend our findings, while Nasim et al. [17] manifested low heritability estimates for the said parameter in Brassica napus. Main raceme length was negatively correlated with all the studied parameters. Our current results are discouraged by Choudhary et al. [24] who reported positive associations for seed yield plant ${ }^{-1}$ with the said parameter (table 4).

\section{Seed pod $^{-1}$}

There was significant $(P \leq O . O 1)$ variations for seed $\operatorname{pod}^{-1}$ (table 1). Samad and Khaleque, [25] reported highly significant variation in $B$. campestris for the said parameter. However Bilgili et al. [26] observed nonsignificant differences for seed $\operatorname{pod}^{-1}$ and discourage our findings. Seed pod $^{-1}$ ranged from 8 to 19. Maximum seed pod $^{-1}$ (19) was observed in genotype J.6o6, whereas minimum seed value (8) was found in genotype J.603. Genetic variance (10.28) was higher in magnitude than environmental variance (1.36) (table 2). High broad-sense heritability (o.88) and moderate selection response (4.34) were recorded for seed pod $^{-1}$ in current study, which suggested that the inheritance and improvement is under genetic control (table 3). High heritability with moderate selection response was resulted by Chaghakaboodi et al. [27] and confirm our result for the said trait.

Seed pod $^{-1}$ showed highly significant positive correlation with primary branches plant ${ }^{-1}\left(\mathrm{r}=0.418^{* *}\right)$, pod length $(\mathrm{r}$ $\left.=0.324^{*}\right)$ and seed yield $\left(\mathrm{r}=0.878^{* *}\right)($ table 4$)$. Similar results of positive and significant correlations between seed pod $^{-1}$ with seed yield were supported by Akbar et al., [28].

\section{Pod length}

Significant $(P \leq O .01)$ differences were exhibited for Pod length (table 1). Previous reports also showed significant values for pod length and encourage our results [10, 20, 22]. Pod length ranged from 1.9 to $4.3 \mathrm{~cm}$. Genotype J.612 showed maximum pod length $(4.3 \mathrm{~cm})$, while minimum length $(1.9 \mathrm{~cm})$ was recorded in genotype J.616 (table 2). Genetic variance (0.34) was good enough in magnitude than environmental variance (0.11) for the said trait. Broad-sense heritability (0.76) was higher in amount however, low selection response (0.73) were recorded for pod length (table 3). Similar findings were obtained by previous studies [29, 30, 17].

Pod length showed significant and positive associations with primary branches per plant $\left(\mathrm{r}=0.407^{* *}\right)$, seed per pod $\left(\mathrm{r}=0.324^{*}\right)$ and seed yield $\left(\mathrm{r}=0.33^{* *}\right)($ table 4$)$. Positive and significant associations between pod length with primary branches plant ${ }^{-1}$ were reported by Ali et al. [2] which confirmed our finding.

\section{Seed yield plant ${ }^{-1}$}

Seed yield plant ${ }^{-1}$ indicated significant $(P \leq O . O 1)$ differences (table 1). These results are in agreement with earlier reports $[22,19]$. Seed yield ranged from 6.17 to $33.83 \mathrm{~g}$. Maximum seed yield ( $33.83 \mathrm{~g}$ ) was observed in genotype J.606, whereas lowest seed yield $(6.17 \mathrm{~g})$ were found in genotype J.609 and J.618 (table 2). Genetic variance (51.62) was much greater than environmental variance (1.33). Highest broad-sense heritability (0.97) and selection response (10.22) were recorded for seed yield (table 3). Khan and Khan, [14] reported high heritability for the said trait and strengthen our results. Seed yield showed highly significant positive associations with primary branches plant ${ }^{-1}\left(\mathrm{r}=0.479^{* *}\right)$, pod length $(\mathrm{r}=$ $\left.0.331^{* *}\right)$ and seed $\operatorname{pod}^{-1}\left(\mathrm{r}=0.878^{* *}\right)$ (table 4). Positive and significant associations between seed yield and primary branches plant ${ }^{-1}$ were observed by Akbar et al. [4] which supported our results. 
Table 1: Mean squares for yield and maturity traits of 20 Brassica juncea germplasm

\begin{tabular}{lllll}
\hline Traits & Replication & Genotype & Error & CV \% \\
\hline Days to half flowering & 24.217 & $157.596^{* *}$ & 37.532 & 8.390 \\
Primary branches plant $^{-1}$ & 1.017 & $12.431^{* *}$ & 3.525 & 17.690 \\
Main raceme length & 23.195 & $273.625^{* *}$ & 53.855 & 12.590 \\
Pod length & 0.101 & $1.138^{* *}$ & 0.110 & 10.530 \\
Seed pod $^{-1}$ & 0.200 & $32.211^{* *}$ & 1.358 & 9.710 \\
Seed yield plant $^{-1}$ & 8.020 & $156.178^{* *}$ & 1.328 & 9.300 \\
\hline
\end{tabular}

Table 2: Ranges with best genotype for yield and maturity traits of 20 Brassica juncea germplasm

\begin{tabular}{lll}
\hline Traits & Range & Best genotype \\
\hline Days to half flowering (no) & $58-89$ & $\mathrm{~J} .617$ \\
Primary branches plant ${ }^{-1}(\mathrm{no})$ & $8-16$ & $\mathrm{~J} .600$ \\
Main Receme Length (cm) & $40.10-77.80$ & $\mathrm{~J} .616$ \\
Pod Length (cm) & $1.90-4.30$ & $\mathrm{~J} .612$ \\
Seed Pod $^{-1}(\mathrm{no})$ & $8-19$ & $\mathrm{~J} .606$ \\
Seed Yield plant $^{-1}(\mathrm{~g})$ & $6.17-33.83$ & $\mathrm{~J} .606$ \\
\hline
\end{tabular}

Table 3: Environmental variances, genotypic variances, phenotypic variances, heritability and selection response for yield and maturity traits of 20 Brassica juncea germplasm

\begin{tabular}{lllll}
\hline Trait & $\mathbf{V}_{\mathbf{e}}$ & $\mathbf{V}_{\mathbf{g}}$ & $\mathbf{h}^{\mathbf{2}}$ & $\mathbf{R}_{\mathbf{e}}$ \\
\hline Days to half flowering (no) & 37.53 & 40.02 & 0.52 & 6.54 \\
Primary branches plant & & \\
Main Receme Length (cm) & 3.53 & 2.97 & 0.46 & 1.68 \\
Pod Length (cm) $_{\text {Seed Pod }^{-1} \text { (no) }}$ & 53.86 & 73.26 & 0.58 & 9.36 \\
Seed Yield plant $^{-1}$ (g) & 0.11 & 0.34 & 0.76 & 0.73 \\
\hline
\end{tabular}

Table 4: Correlation analysis for yield and maturity traits of 20 Brassica juncea germplasm

\begin{tabular}{|c|c|c|c|c|c|}
\hline Traits & $\begin{array}{l}\text { Primary branches plant } \\
\text { 1 }\end{array}$ & $\begin{array}{l}\text { Main raceme } \\
\text { length }\end{array}$ & $\begin{array}{l}\text { Pod } \\
\text { length }\end{array}$ & $\begin{array}{l}\text { Seed pod- } \\
1\end{array}$ & $\begin{array}{l}\text { Seed yield- } \\
1\end{array}$ \\
\hline $\begin{array}{l}\text { Days to half flowering } \\
\text { Primary branches plant }\end{array}$ & $0.337^{* *}$ & $\begin{array}{l}-0.066 \\
-0.124\end{array}$ & $\begin{array}{l}0.199 \\
0.407^{* *}\end{array}$ & $\begin{array}{l}0.211 \\
0.418^{* *}\end{array}$ & $\begin{array}{l}0.127 \\
0.479 * *\end{array}$ \\
\hline $\begin{array}{l}\text { Main raceme length } \\
\text { Pod length } \\
\text { Seed pod }{ }^{-1}\end{array}$ & & & -0.22 & $\begin{array}{l}-0.15^{2} \\
0.324^{*}\end{array}$ & $\begin{array}{l}-0.111 \\
0.331^{* *} \\
0.878^{* *} \\
\end{array}$ \\
\hline
\end{tabular}

\section{CONCLUSION}

It is clear from the results that high genetic variability in the studied genotypes is great scope for selection. Traits like seed pod $^{-1}$ and seed yield plant ${ }^{-1}$ has high heritability and selection can be based on these traits. Based on genetic parameters and mean performance, genotypes J.600, J.606 and J.616 were superior and hence can be recommended in breeding programs.

\section{ACKNOWLEDGEMENT}

We are very thankful to Department of Plant Breeding and Genetics, The University of Agriculture, PeshawarPakistan for providing Brassica Juncea germplasm and also field area to carry out the proposed research work.

\section{REFERENCES}

1. Zhang G and Zhou W. Genetic analyses of agronomic and seed quality traits of synthetic oilseed brassica napus produced from inter specific hybridization of brassica campestris and brassica olearacea. Journal of Genetics. 2006;85: 45-51.
2. Syed AS, Ali I, Rahman K. Improvement of rapeseed for agronomic and quality characters through induced mutations and hybridization. In: Mutation Breeding of Oil Seed Crops, Proceedings of a final Research Coordination Meeting of an FAO/IAEA Coordinated Research Progamme Vienna. 1994;11-15 Jan. 1993. IAEA-TECDOC-781, ISSN 1011-4289. pp. 25-35.

3. Ali Y, Farhatullah, Rahman H, Nasim A, Azam SM, Khan A. Heritability and correlation analysis for morphological and biochemical traits in brassica carinata. Sarhad Journal of Agriculture. 2013;29: 359-369.

4. Shukla S, Bhargava A, Chatterjee A, Sirivastava J, Singh N, Singh SP. Mineral profile and variability in vegetable amaranth (Amaranthus tricolor). Plant Foods for Human Nutrition. 2006;61, 23-28.

5. Akbar M, Mahmood T, Yaqub M, Anwar M, Ali M, Iqbal N. (2003). Variability, correlation and path coefficient studies in summer mustard (Brassica juncea L.). Asian Journal of Plant Sciences. 2: 696698.

6. Jatoi SA, Javaid A, Iqbal M, Sayal OU, Masood MS, Siddiqui SU. Genetic diversity in radish germplasm 
for morphological traits and seed storage proteins. Pakistan Journal of Botany. 2012;43: 2507-2512.

7. Zada M, Shinwari ZK, Zakir N, Rabbani MA. Study of total seed storage proteins in Ethiopian mustard (Brassica carinata a. braun) germplasm. Pakistan Journal of Botany. 2013;45: 443-448.

8. Khan FA, Ali S, Shakeel A, Saeed A, Abbas G. Genetic variability and genetic advance analysis for some morphological traits in B. napus L. Journal of Agricultural Research. 2006;44: 83-88.

9. Shukla S, Bhargava A, Chatterjee A, Singh SP. Estimates of genetic parameters to determine variability for foliage yield and its different quantitative and qualitative traits in vegetable amaranth (A. tricolor). Journal of Genetics and Breeding. 2004;58, 169-176.

10. Aytaç Z, Kinaci G. Genetic variability and association studies of some quantitative characters in winter rapeseed (Brassica napus L.). African Journal of Biotechnology. 2009;8: 3547-3554.

11. Steel RGD, Torrie JH. Principles and Procedures of Statistics. McGraw Hill Book Co., Inc. New York, USA. 1980.

12. Singh M, Ceccarelli S. Estimation of heritability of crop traits from variety trial data. Technical Manual, International Center for Agricultural Research in the Dry Areas, Aleppo, Syria. 1996;p. 21.

13. Fehr WR. (1993). Principles of cultivar development: Vol. I. Theory and techniques. McMillan Pub. Co., USA.

14. Khan RSA, Khan FA. Evaluation of genetic potential of some brassica germplasm collections. International Journal of Agriculture and Biology. 2003;4, 630-631.

15. Nazeer A, Javidfar F, Elmira JY, Mirza M. Relationship among yield components and selection criteria for yield improvement in winter rapeseed (Brassica napus L.). Pakistan Journal of Botany. 2003;35, 167-174.

16. Mahto JL, Haider ZA. Variability studies in Indian mustard under six different environments in acidic soil. Crucif. Newsletter. 2002;24, 13-14.

17. Nasim A, Farhatullah, Iqbal S, Shah S, Azam SM. Genetic variability and correlation studies for morpho-physiological traits in Brassica napus $\mathrm{L}$. Pakistan Journal of Botany. 2013;45: 1229-1234.

18. Gangapur DR, Prakash BG, Salimath PM, Ravikumar $\mathrm{RL}$, Rao MSL. Correlation and path analysis in Indian mustard (Brassica juncea L. Czern and Coss). Karnataka Journal of Agricultural Sciences. 200922: 971-977.
19. Ghosh SK, Gulati SC. Genetic variability and association of yield components in Indian mustard. Crop Research Hissar. 2001;21, 345-349.

20. Azadgoleh MA, Zamani M, Yasari E. Agronomical important traits correlation in rapeseed (B. napus L.) genotypes. Research Journal of Agriculture and Biological Sciences. 2009;5: 798-802.

21. Iqbal S, Farhatullah, shah S, Kanwal M, Fayyaz L, Afzal M. Genetic variability and heritability studies in indigenous brassica rapa accessions. Pakistan Journal of Botany. 2014;46: 609-612.

22. [22]Tahir MHN, Bashir S, Bibi A. Genetic potential of canola (Brassica napus L.) varieties under water stress conditions. Caderno de Pesquisasér. Bio. 2006;18: 127-135.

23. Muhammad A, Raziuddin, Muhammad A, Raza H, Rahman AU, Ali I. Combining ability and heritability studies for important traits in F2 of brassica napus. International Journal of Basic and Applied Sciences. 2014;14: 7-11.

24. Choudhary VK, Rakeshkumar, Sah JN. Path analysis in Indian mustard. Journal of Applied Biology. 2003;13(1/2): 6-8.

25. Samad A, Khaleque MA. Diversity estimates of yield and some of the agronomical characters in rapeseed (Brassica campestris L.). Bangladesh Journal of Scientific and Industrial Research. 2000;35(1-4): 2026.

26. Bilgili M, Sincik, Uzun A, Acikgoz E. The Influence of row spacing and seeding rate on seed yield and yield components of forage turnip (Brassica rapa L.). Journal of Agronomy and Crop Science. 2002;189, 250-254.

27. Chaghakaboodi Z, Kahrizi D, Zebarjadi A. Heritability and genetic advance in rapeseed (Brassica napus L.). Iranian Journal of Genetics and Plant Breeding. 2012;1: 16-21.

28. Akbar M, Saleem U, Tahira, Yaqub M, Iqbal N. Utilization of genetic variability, correlation and path analysis for seed yield improvement in mustard, B. juncea L. Journal of Agricultural Research. 2007;45: 25-31.

29. Khan S, Farhatullah, Khalil IH, Khan MY, Ali N. Genetic variability, Heritability and correlation for some quality traits in $\mathrm{F}_{3}: 4$ brassica populations. Sarhad Journal of Agriculture. 2008;24: 223-231.

30. Sheikh IA, Singh JN. Combining ability of seed yield and oil content in (B. juncea). Indian Journal of Genetics. 1998;58, 507-511. 